\title{
Osmotic adjustment in Pinus pinaster cuttings in response to a soil drying cycle
}

\author{
Anne Nguyen-Queyrens ${ }^{\mathrm{a}^{*}}$, Paulo Costa ${ }^{\dagger \mathrm{b}}$, Denis Loustau $^{\mathrm{a}}$ and Christophe Plomion ${ }^{\mathrm{b}}$ \\ ${ }^{a}$ Laboratoire Écophysiologie et Nutrition, Institut National de la Recherche Agronomique, \\ Unité de Recherches Forestières de Bordeaux-Cestas, Domaine de l'Hermitage, Pierroton, Gazinet, 33611, France \\ ${ }^{\mathrm{b}}$ Laboratoire Génétique et Amélioration des Arbres Forestiers, Institut National de la Recherche Agronomique, \\ Unité de Recherches Forestières de Bordeaux-Cestas, Domaine de l'Hermitage, Pierroton, Gazinet, 33611, France
}

(Received 3 December 2001; accepted 19 February 2002)

\begin{abstract}
Two-year-old cuttings of five genotypes of maritime pine (Pinus pinaster Ait.) were subjected to a four-month treatment of slowly decreasing water availability in pots. Final predawn needle water potential varied from -0.82 to $-1.48 \mathrm{MPa}$, and was negatively correlated with plant size. Osmotic adjustment was estimated as the slope of the regression line fitted between relative water content (RWC) and osmotic potential $(\Psi \pi)$ assessed during the drying cycle, and as the value of the relative water content for a given level of $\Psi \pi$ (i.e. $\Psi \pi=-1.7 \mathrm{MPa}$ ). Under the experimental conditions, the genotypes showed a high capacity for osmotic adjustment in needles, and one genotype distinguished itself with a smaller capacity. The results are discussed in terms of protocol and interpretation when ranking genotypes for osmotic adjustment.
\end{abstract}

osmotic adjustment / drought / Pinus pinaster

Résumé - Ajustement osmotique de boutures de Pinus pinaster en réponse à un dessèchement du sol. Des boutures issues de 5 génotypes de pin maritime (Pinus pinaster Ait.) et âgées de 2 ans ont été soumises en pot à un arrosage décroissant lentement au cours du temps pendant 4 mois. Les valeurs finales de potentiel hydrique foliaire de base variaient entre $-0,82$ et $-1,48 \mathrm{MPa}$, et étaient négativement corrélées à la taille du plant. L'ajustement osmotique a été estimé par la pente de la régression entre le contenu relatif en eau (RWC) et le potentiel osmotique ( $\Psi \pi$ ), les données étant prises durant le cycle de sécheresse, et par la valeur du contenu relatif en eau pour un niveau choisi de $\Psi \pi$ (i.e. $\Psi \pi=-1,7 \mathrm{MPa}$ ). Dans les conditions de l'expérience, les génotypes ont montré une capacité significative d'ajustement osmotique dans les aiguilles et un génotype différait des quatre autres par une plus faible capacité. Les résultats sont discutés en termes de protocole et interprétation dans le but de classer des génotypes pour la capacité d'ajustement osmotique.

ajustement osmotique / sécheresse / Pinus pinaster

\section{INTRODUCTION}

Maritime pine (Pinus pinaster Ait.) is widely established in monospecific stands and is found over more than 4 million ha in southwestern Europe and northern Africa. In France, this species is bred according to a recurrent selection scheme, for growth capacity and stem straightness, and the breeding population is presently in its third generation [2]. In the context of global change, breeders are particularly interested in selecting genotypes which maintain growth performance under drought conditions. Because of its high stomatal sensitivity to soil water deficit, maritime pine is considered to be a drought-avoiding species [13, 27]. Earlier studies have revealed variability in ecophysiological response to drought among geographical races $[11,12,14,15,24,25,27]$ and among full-sib families within a French population [14]. The need for standard screening tests is hampered, however, by the difficulty in characterizing water stress tolerance.

\footnotetext{
* Correspondence and reprints

Tel.: +33 5579790 67; fax: +33 5566805 46; e-mail: queyrens@ pierroton.inra.fr
} 
Promising perspectives have arisen with the measurement of water use efficiency via the isotopic approach (i.e. ${ }^{13} \mathrm{C}[14$, 27]). Other studies have aimed at identifying drought-responsive proteins $[9,10]$, or quantitative trait loci $(\mathrm{QTL})$ of diverse physiological traits believed to be related to drought resistance [8]. There is however insufficient knowledge about the adaptative processes involved for evaluating the water stress tolerance of a genotype. Osmotic adjustment (OA), defined as the lowering of osmotic potential due to net solute accumulation, is recognized as a major component of drought resistance for annual and woody plants [7, 22, 26, 32, 33]. Reduced osmotic potential allows the plant to maintain turgor, and therefore turgor-dependent processes such as cell expansion and stomatal aperture, even at low water potential. From a previous experiment, we have evidence of osmoregulation in roots tips of a drought-resistant Pinus pinaster population from Morocco [24]. Fernandez et al. [11] found a significant decrease in osmotic potential at full turgor in $P$. pinaster shoots subjected to water stress treatment. In contrast to these results, Picon-Cochard and Guehl [28] did not observe soluble carbohydrate accumulation in $P$. pinaster seedling needles subjected to a soil drying cycle. But insufficient duration and severity $\left(-0.25 \mathrm{MPa} \mathrm{day}^{-1}\right)$ of the applied water stress in this last study probably suppressed the expression of OA $[1,6,16,31]$.

In the present study, two-year-old cuttings of several $P$. pinaster genotypes were submitted to gradual soil water depletion. The objectives were to assess the occurrence of $\mathrm{OA}$ in needles and to quantify the degree of $\mathrm{OA}$ for adequate genotype comparison. The most commonly used methods to quantify the OA capacity of plants are via: (i) regression of leaf relative water content (RWC) against leaf osmotic potential $(\Psi \pi)$ [21], (ii) extrapolation of the osmotic potential for stressed plants to the rehydrated state [20], (iii) osmotic potential of stressed plants that have been rehydrated [4]. The first method requires measurement of RWC and $\Psi \pi$ at intervals during a drying cycle. The two other methods are more suitable for screening large numbers of genotypes, but as the OA magnitude depends on the degree of water stress, the measurements must be performed all at the same tissue water status. When diverse genetic materials are compared, this last condition requires normalization for plant tissue water deficit, which is critical when the genotypes also differ in size, root traits or any other plant factors that determine the rate of plant dehydration in a pot. These differences are often enhanced in woody material compared to herbaceous plants. Recently, Babu et al. [1] compared these three methods on the same plant material (12 rice cultivars) and found a wider range of $\mathrm{OA}$ values estimated with the first method than with the two other methods. Method (i) has been applied widely to crop plants $[18,19,21,36]$ but apparently never to woody species. In the present work, we evaluate the possibility of using this method to differentiate genotypes for $\mathrm{OA}$ in $P$. pinaster.

\section{MATERIALS AND METHODS}

\subsection{Plant material and water stress application}

Cuttings, propagated from five maritime pine seedlings (Pinus pinaster Ait.) were provided by the Forest Genetics and Breeding Laboratory (INRA, Bordeaux-Cestas). These five genotypes (A241, A250, A395, B96, C55) were obtained by self-pollination of hybrids resulting from crosses between an atlantic and a mediterranean population (Landes $\times$ Corse), selecting for growth capacity and stem straightness. Three cuttings per genotype were obtained for this study. These cuttings were first grown in a greenhouse for six months, and then transplanted into $4 \mathrm{~L}$ containers filled with $1 / 1 / 1$ of sand/peat/bark (v/v/v) and nutrients (10 g of Osmocote Plus, Scotts France; $15 \% \mathrm{~N}, 10 \% \mathrm{P}, 12 \% \mathrm{~K}, 2 \% \mathrm{Mg})$. The cuttings ranged from 34 to $71 \mathrm{~cm}$ (Hi = initial height) when two years old. They were randomly distributed on a table in a glasshouse and grown at day/night temperatures of $25 \pm 5^{\circ} \mathrm{C} / 17.5 \pm 2.5^{\circ} \mathrm{C}$ and $70 \pm 10 \%$ relative humidity for 124 days of water stress treatment (May 3rd = day 0 ). During the first two weeks of water stress, $60 \%$ of the water required to attain field capacity was supplied to each pot every other day. The water supply was then reduced sequentially to $40 \%, 30 \%$ and $20 \%$ of that required for field capacity during respectively 1,1 and 2 months (the water required for field capacity was calculated by weighing each well-watered pot before the water stress treatment). The container surface was covered with a synthetic sponge to minimize evaporation. The height increment $(\Delta \mathrm{H})$ during the treatment period was assessed as the fraction of initial height.

\subsection{Plant water relations}

Predawn water potential ( $\left.\Psi_{\mathrm{wp}}, \mathrm{MPa}\right)$ was measured four times (after $0,32,74$ and 124 days) with a Scholander pressure chamber $[29,30]$ on one-year-old needles of each plant. Immediately after each $\Psi_{\text {wp }}$ measurement, another needle was harvested and weighed for relative water content (RWC) and osmotic potential at full turgor $\left(\Psi_{\Pi 100}\right)$ measurements. The proximal end was submerged, severed, and kept in water at $5{ }^{\circ} \mathrm{C}$ in darkness $(24 \mathrm{~h})$ for full rehydration. The needle was then rapidly dried with a paper towel, weighed and frozen at $-20{ }^{\circ} \mathrm{C}$ in an Eppendorf tube. For the $\Psi_{\Pi 100}$ measurement, the needle was cut into small pieces (2-3 mm long) and placed in a $2 \mathrm{~mL}$ syringe: needle sap was squeezed out after freezing (in liquid nitrogen) and thawing. Sap osmolality was measured in $10 \mu \mathrm{L}$ samples using a vapor pressure osmometer (Vapro R Model 5520, Wescor, Logan, USA). Needle dry weight $\left(70^{\circ} \mathrm{C}, 48 \mathrm{~h}\right)$ was then determined. From these measurements, relative water content (RWC) and osmotic potential $\left(\Psi_{\Pi}\right)$ were calculated as follows:

$$
\mathrm{RWC}=(\mathrm{FW}-\mathrm{DW}) /\left(\mathrm{FW}_{100}-\mathrm{DW}\right)
$$$$
\Psi_{\Pi}=\left(\Psi_{\Pi 100} \times 100\right) / \text { RWC; }
$$

where: $\mathrm{FW}=$ needle fresh weight at predawn water potential; DW = needle dry weight; $\mathrm{FW}_{100}=$ needle fresh weight at full hydration.

Osmotic adjustment (OA), was considered to occur when the tissue behavior differed from that of a passive osmometer. In the case of a passive osmometer, $\ln \mathrm{RWC}=-\mathrm{A} \ln \left(-\Psi_{\Pi}\right)+\mathrm{B}$, and $\mathrm{A}=1$ [21] . When the increase in solute concentration was more than that resulting from a decrease in water content (the passive component), then osmoregulation was active and A was less than 1. The degree of osmotic adjustment for each genotype was therefore studied through the relationship between $\ln \mathrm{RWC}$ and $-\ln \left(-\Psi_{\Pi}\right)[21,23]$ as the plants were submitted to gradual water stress. Some authors [5, 23, 34] have also expressed osmotic adjustment capacity as the relative water content, derived from the function fitted to the data, evaluated 
at a given $\Psi_{\Pi}$. We chose to calculate RWC at $-1.7 \mathrm{MPa}\left(\mathrm{RWC}_{-1.7}\right)$, a value observed for all studied genotypes.

\section{RESULTS AND DISCUSSION}

Table I displays the mean values of predawn needle water potential $\left(\Psi_{\mathrm{wp}}\right)$. After 74 days of treatment, the genotype A241 exhibited significantly lower values than the other genotypes. Cuttings of this genotype were also the tallest ( $t a-$ ble II). Although whole plant leaf area was not estimated, it can be suggested that taller cuttings likely had larger transpiring leaf area and so consumed more water. When subjected to water limitation in a restricted rooting volume, these cuttings were expected to show rapidly decreasing values of water potential. Among all studied cuttings, a significant negative relationship was found between $\Psi_{\mathrm{wp}}$ (day 124) and $\mathrm{Hi}$ : $\Psi_{\text {wp }}($ day 124$)=-0.0014 \mathrm{Hi}-0.288 ; \mathrm{R}^{2}=0.42 ; \mathrm{Pr}>\mathrm{F}=0.013$. Plant size was thus a source of water status variability, an effect that was accentuated when the seedlings were grown and submitted to water deficit in pots. The strictly genotypical influence on height, architecture and biomass traits, though not easy to evaluate, constitute drought resistance components through plant water requirements. For this reason, experiments at early ages are far from sufficient. Whatever the origin of plant size differences (genotypical or environmental), the effect of plant size is often not taken into account or even confounded with the effect of plant function [3].

Table I. Mean value \pm standard deviation ( $\mathrm{N}=3$ cuttings) of the predawn needle water potential ( $\Psi$ wp). Within a column, means with the same letter are not significantly different at $P=0.05$.

\begin{tabular}{lcccc}
\hline & \multicolumn{4}{c}{$\Psi w p(\mathrm{MPa})$} \\
\hline $\begin{array}{l}\text { Days of stress } \\
\text { treatment }\end{array}$ & 0 & 32 & 74 & 124 \\
$\begin{array}{l}\text { Genotype } \\
\text { A250 }\end{array}$ & $-0.58 \pm 0.08 \mathrm{a}$ & $-0.66 \pm 0.06 \mathrm{a}$ & $-0.72 \pm 0.10 \mathrm{ab}$ & $-0.86 \pm 0.30 \mathrm{a}$ \\
C55 & $-0.54 \pm 0.13 \mathrm{a}$ & $-0.58 \pm 0.05 \mathrm{a}$ & $-0.66 \pm 0.04 \mathrm{a}$ & $-0.82 \pm 0.20 \mathrm{a}$ \\
B96 & $-0.53 \pm 0.04 \mathrm{a}$ & $-0.64 \pm 0.09 \mathrm{a}$ & $-0.64 \pm 0.15 \mathrm{a}$ & $-1.08 \pm 0.25 \mathrm{ab}$ \\
A395 & $-0.64 \pm 0.21 \mathrm{a}$ & $-0.76 \pm 0.12 \mathrm{a}$ & $-0.88 \pm 0.14 \mathrm{ab}$ & $-1.02 \pm 0.04 \mathrm{a}$ \\
A241 & $-0.73 \pm 0.04 \mathrm{a}$ & $-0.89 \pm 0.22 \mathrm{a}$ & $-0.94 \pm 0.18 \mathrm{~b}$ & $-1.48 \pm 0.04 \mathrm{~b}$ \\
\hline
\end{tabular}

Table II. Mean value \pm standard deviation ( $\mathrm{N}=3$ cuttings) of initial height (Hi) and height increment during the treatment period $(\Delta \mathrm{H})$. Genotype means with the same letter are not significantly different at $P=0.05$.

\begin{tabular}{ccc}
\hline Genotype & Hi $(\mathrm{mm})$ & $\Delta H(\%)$ \\
\hline A250 & $347 \pm 80 \mathrm{c}$ & $14.9 \pm 0.9 \mathrm{ab}$ \\
C55 & $473 \pm 87 \mathrm{~b}$ & $17.5 \pm 7.3 \mathrm{a}$ \\
B96 & $647 \pm 51 \mathrm{a}$ & $8.6 \pm 2.8 \mathrm{bc}$ \\
A395 & $577 \pm 59 \mathrm{a}$ & $9.7 \pm 2.8 \mathrm{bc}$ \\
A241 & $680 \pm 36 \mathrm{a}$ & $5.1 \pm 1.8 \mathrm{c}$ \\
\hline
\end{tabular}

Height growth during the water stress treatment $(\Delta \mathrm{H}$, table II) showed some variation among genotypes, but was mainly a response to better hydrated tissue: the effect of the final predawn water potential $\left(\Psi_{\mathrm{wp}}\right.$, day 124$)$ was highly significant for $\Delta \mathrm{H}(\mathrm{F}$ value $=3.22, \operatorname{Pr}>\mathrm{F}=0.0073)$.

Both osmotic potential $\left(\Psi_{\Pi}\right)$ and relative water content (RWC) declined with increasing stress and a positive relationship was found between them (figure 1). The regression coefficients were rather small $\left(\mathrm{R}^{2}=0.36\right.$ to 0.59$)$ compared to values calculated for sunflower cultivars $\left(R^{2}=0.70\right.$ to 0.97 , $\mathrm{n}=9$ to 11 , [5]), but similar to some data for maize hybrids $\left(R^{2}=0.61, n=10,[17]\right)$. This may be due to reduced precision in RWC and $\Psi_{\Pi}$ due to the structural rigidity and the presence of wax in conifer needles, which prevent adequate water exchange during tissue handling. Thus, increasing the number of samples per tested genotype is recommended for further studies.

All genotypes showed some degree of osmotic adjustment (i.e. the relationship differed from a line of slope 1) and a genotypical difference was demonstrated in table III by the significant interaction between the genotype and the logarithmic value of $\Psi_{\Pi}$. This difference was, however, mainly due to the contrasted behavior of the genotype A241, which exhibited a high value of the regression slope. The slopes were much lower than those previously reported for rice lines $(0.58$ to $1.16,[19])$ or sunflower cultivars (0.5 to $1.6,[5])$, except for genotype A241 (0.277), which was similar to some maize hybrids $(0.16$ to $0.92,[17])$. These values indicate that the studied $P$. pinaster genotypes presented a great ability for $\mathrm{OA}$. However, the very gradual drought applied in the present study $\left(-0.28\right.$ to $-0.75 \mathrm{MPa}$ of $\Psi_{\text {wp }}$ variation in about 4 months) may have influenced the measured level of OA [6, 31]. While gradual application of stress is needed to allow plants to respond, if the stress develops too slowly, genotype differences may be difficult to detect when physiological responses are maximized. The small slopes found in the present study could reflect high solute accumulation provoked by

Table III. Variance analysis of the dependent variable ln (RWC). (A) effects of the genotype and of the relation with the logarithmic value, $-\ln \left(-\Psi_{\Pi}\right)$; (B) for each genotype, relation with the logarithmic value, $-\ln \left(-\Psi_{\Pi}\right)$; (general linear model procedure, type III SS, SAS Institute Inc., release 6.03).

Variance analysis of the dependent variable $\ln (\mathrm{RWC})$

\begin{tabular}{|c|c|c|c|c|c|}
\hline \multicolumn{2}{|l|}{ (A) Source } & \multicolumn{2}{|l|}{ F value } & \multicolumn{2}{|l|}{$\operatorname{Pr}>F$} \\
\hline \multirow{3}{*}{\multicolumn{2}{|c|}{$\begin{array}{l}\text { Genotype } \\
-\ln \left(-\Psi_{\Pi}\right) \\
\text { interaction }\end{array}$}} & \multirow{2}{*}{\multicolumn{2}{|c|}{$\begin{array}{l}2.25 \\
30.09\end{array}$}} & \multicolumn{2}{|l|}{0.0872} \\
\hline & & & & 0.0001 & \\
\hline & & \multicolumn{2}{|l|}{3.64} & \multicolumn{2}{|l|}{0.0155} \\
\hline (B) Source & Genotype & Slope & Standard error & $\mathrm{T}$ & $\operatorname{Pr}>\mathrm{T}$ \\
\hline \multirow[t]{5}{*}{$-\ln \left(-\Psi_{\Pi}\right)$} & A 250 & $0.026 \mathrm{~b}$ & 0.013 & 1.98 & 0.105 \\
\hline & C55 & $0.029 \mathrm{~b}$ & 0.014 & 2.12 & 0.079 \\
\hline & B96 & $0.073 \mathrm{~b}$ & 0.036 & 2.01 & 0.084 \\
\hline & A395 & $0.075 \mathrm{~b}$ & 0.029 & 2.60 & 0.041 \\
\hline & A241 & $0.277 \mathrm{a}$ & 0.093 & 2.98 & 0.025 \\
\hline
\end{tabular}




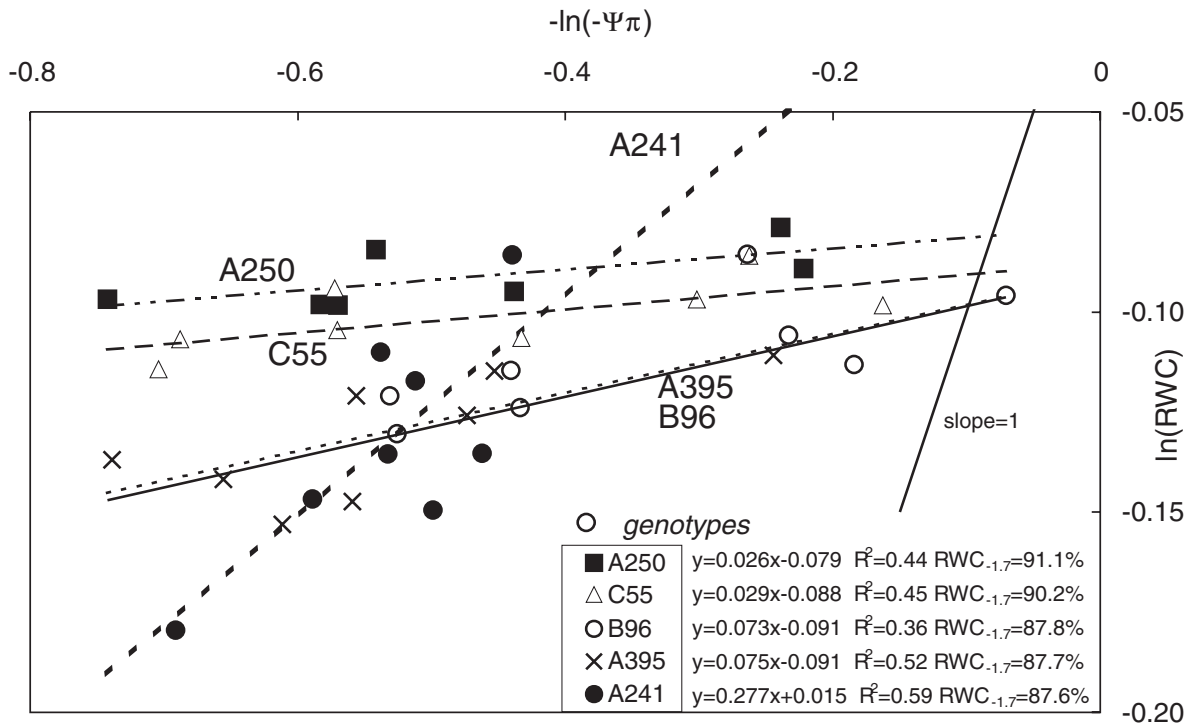

Figure 1. Logarithmic plots of relative water content against osmotic potential of one year-old needles: $\ln \mathrm{RWC}=\mathrm{f}(-\ln$ $\left(-\Psi_{\Pi}\right)$ ). The response of each genotype is described by the slope of the fitted line $(\mathrm{N}=7$ to 8$)$, and by the calculated $\mathrm{RWC}_{-1.7}$ value (RWC value for $\Psi_{\Pi}=$ $-1.7 \mathrm{MPa})$ some drought hardening processes. Further studies are needed to investigate the optimum stress development rate to express actual OA capacity in drought-prone conditions.

The values of $\mathrm{RWC}_{-1.7}$ were found to vary between 87.6 and $91.1 \%$ (figure 1 ) and decreased as the slope of the corresponding fitted line increased, confirming genotype ranking according to slope. The relative water content at a given $\Psi_{\Pi}$, and the $\Psi_{\Pi}$ value varie with both investigator and species, summarize the effects of the variations in the ln $\mathrm{RWC} /\left(-\ln \left(-\Psi_{\Pi}\right)\right)$ relationship, and are calculated by many authors as an indicator of OA. The above reservations notwithstanding, our five studied genotypes would seem to show a greater capacity for $\mathrm{OA}$ than maize $\left(\mathrm{RWC}_{-1.64}=54.5 \%\right.$ to $77.7 \%,[17])$ or sunflower cultivars $\left(\mathrm{RWC}_{-1.7}=41.1 \%\right.$ to $91.1 \%,[5])$. Such a comparison between herbaceous species and wood species is limited in its physiological interpretation, since water loss occurs in maritime pine at a relative water content of around $80 \%$ (unpublished results), while it is mainly observed at $60-70 \% \operatorname{RWC}[5,35]$ for herbaceous plants.

Our results demonstrate the occurrence of OA by $P$. pinaster needles in response to a very gradually applied soil water deficit. Evaluating the degree of OA through the $\ln \mathrm{RWC} /\left(-\ln \left(-\Psi_{\Pi}\right)\right)$ relationship is possible in this forest species, but the final protocol for a standard genotype testing system remains to be determined with the precautions emphasized in the present study. In addition, the values reported here should be interesting in comparison with similar experiments on other woody species. Estimating the value of OA as a selection criterion requires knowledge of the relationship between OA capacity and genetic differences in waterstressed growth performance.

Acknowledgements: The authors are grateful to J.L. Grange and E. Bertocchi for technical handling in the greenhouse, assistance in cutting preparation and harvesting, and E. Dreyer for advice in writing the earlier version of the manuscript. The investigations were financially supported by the European Union FAIR1 CT95-0781 project: "Genetic, molecular and physiological determinants of water-use efficiency and drought resistance in major forest trees" (DELTA), and two national programs ACC-SV3 (the Research and Education Ministry) and CTPS (the Agricultural Ministry).

\section{REFERENCES}

[1] Babu R.C., Pathan M.S., Blum A., Nguyen H.T., Comparison of measurement methods of osmotic adjustment in rice cultivars, Crop Sci. 39 (1999) $150-155$.

[2] Baradat P., Pastuszka P., Le pin maritime, in: Gallais A., Bannerot H. (Eds.), Amélioration des Espèces Végétales Cultivées, INRA, Paris, 1992, pp. 695-709.

[3] Blum A., Towards standard assays of drought resistance in crop plants, in: Molecular approaches for the genetic improvement of cereals for stable production in water-limited environments, Proc. Symp. Cimmyt headquarters, Mexico, June 21-25, 1999, 11 p.

[4] Blum A., Sullivan C.Y., The comparative drought resistance of landraces of sorghum and millet from dry and humid regions, Ann. Bot. 57 (1986) 835-846.

[5] Chimenti C.A., Hall A.J., Genetic variation and changes with ontogeny of osmotic adjustment in sunflower (Helianthus annuиs L.), Euphytica 71 (1993) 201-210.

[6] Collet C., Guehl J.M., Osmotic adjustment in sessile oak seedlings in response to drought, Ann. Sci. For. 54 (1997) 389-394.

[7] Colombo S.J., Changes in osmotic potential, cell elasticity, and turgor relationships of 2nd-year black spruce container seedlings, Can. J. For. Res. 17 (1987) 365-369.

[8] Costa P., Réponse moléculaire, physiologique et génétique du pin maritime à une contrainte hydrique, Thesis, Université Nancy I, France, 1999.

[9] Costa P., Bahrman N., Frigerio J.M., Kremer A., Water-deficit-responsive proteins in maritime pine, Plant Mol. Biol. 38 (1998) 587-596.

[10] Costa P., Plomion C., Genetic analysis of needle proteins in maritime pine: 2. Variation of protein accumulation, Silvae Genet. 48 (1999) 146-150. 
[11] Fernandez M., Gil L., Pardos J.A., Response of Pinus pinaster Ait. provenances at early age to water supply. I. Water relation parameters, Ann. For. Sci. 56 (1999) 179-187.

[12] Fernandez M., Gil L., Pardos J.A., Effects of water supply on gas exchange in Pinus pinaster Ait. provenances during their first growing season, Ann. For. Sci. 57 (2000) 9-16.

[13] Granier A., Loustau D., Measuring and modelling the transpiration of a maritime pine canopy from sap-flow data, Agric. For. Meteorol. 71 (1994) $61-81$.

[14] Guehl J.M., Nguyen-Queyrens A., Loustau D., Ferhi A., Genetic and environmental determinants of water-use efficiency and carbon isotope discrimination in forest trees, in: INRA (Ed.), EUROSILVA, Contribution to Forest Tree Physiology, Colloq. INRA No.76, Dourdan, France, November 7-10, 1994, pp. 297-321.

[15] Guyon J.P., Kremer A., Stabilité phénotypique de la croissance en hauteur et cinétique journalière de pression de sève et de la transpiration chez le pin maritime (Pinus pinaster Ait.), Can. J. For. Res. 12 (1982) 936-946.

[16] Jones M.M., Rawson H.M., Influence of rate of development of leaf water deficits upon photosynthesis, leaf conductance, water use efficiency, and osmotic potential in Sorghum, Physiol. Plant 45 (1979) 103-111.

[17] Lemcoff J.H., Chimenti C.A., Davezac T.A.E., Osmotic adjustment in maize (Zea mays L.): changes with ontogeny and its relationship with phenotypic stability, J. Agron. Crop Sci. 180 (1998) 241-247.

[18] Lilley J.M., Ludlow M.M., Expression of osmotic adjustment and dehydration tolerance in diverse rice lines, Field Crops Res. 48 (1996) 185-197.

[19] Lilley J.M., Ludlow M.M., McCouch S.R., O’Toole J.C., Locating QTL for osmotic adjustment and dehydration tolerance in rice, J. Exp. Bot. 47 (1996) 1427-1436.

[20] Ludlow M.M., Chu A.C.P., Clements R.J., Kerslake R.G., Adaptation of species of Centromesa to water stress, Aust. J. Plant Physiol. 10 (1983) $119-130$.

[21] Morgan J.M., Osmotic adjustment in the spikelets and leaves of wheat, J. Exp. Bot. 31 (1980) 655-665.

[22] Morgan J.M., Osmoregulation and water stress in higher plants, Annu. Rev. Plant Physiol. 35 (1984) 299-319.

[23] Morgan J.M., Growth and yield of wheat lines with differing osmoregulative capacity at high soil water deficit in seasons of varying evaporative demand, Field Crops Res. 40 (1995) 143-152.
[24] Nguyen A., Lamant A., Variation in growth and osmotic regulation of roots of water-stressed maritime pine (Pinus pinaster Ait.) provenances, Tree Physiol. 5 (1989) 123-133.

[25] Nguyen-Queyrens A., Ferhi A., Loustau D., Guehl J.M., Within $\delta^{13} \mathrm{C}$ spatial variability and interannual variations in wood cellulose of two contrasting provenances of Pinus pinaster, Can. J. For. Res. 28 (1998) 766-773.

[26] Osonubi O., Davies W.J., Solute accumulation in leaves and roots of woody plants subjected to water stress, Oecologia 32 (1978) 323-332.

[27] Picon C., Guehl J.M., Ferhi A., Leaf gas-exchange and carbon isotope composition responses to drought in a drought-avoiding (Pinus pinaster) and a drought tolerant (Quercus petraea) species under present and elevated atmospheric $\mathrm{CO}_{2}$ concentrations, Plant Cell Environ. 19 (1996) 182-190.

[28] Picon-Cochard C., Guehl J.M., Leaf gas exchange and carbohydrate concentrations in Pinus pinaster plants subjected to elevated $\mathrm{CO}_{2}$ and a soil drying cycle, Ann. For. Sci. 56 (1999) 71-76.

[29] Ritchie G.A., Hinckley T.M., The pressure chamber as an instrument for ecological research, Adv. Ecol. Res. 9 (1975) 165-254.

[30] Scholander P.F., Hammel H.T., Bradstreet E.D., Hemmingsen E.A., Sap pressure in vascular plants, Science 148 (1965) 339-346.

[31] Shangguan Z., Shao M., Dyckmans J., Interaction of osmotic adjustment and photosynthesis in winter wheat under soil drought, J. Plant Physiol. 154 (1999) 753-758.

[32] Turner N.C., Jones M.M., Turgor maintenance by osmotic adjustment, a review and evaluation, in: Turner N.C., Kramer P.J. (Eds.), Adaptation of plants to water and high temperature stress, Wiley-Interscience, New York, 1980, pp. 87-103.

[33] Vivin P., Guehl J.M., Clément A., Aussenac G., The effects of elevated $\mathrm{CO}_{2}$ and water stress on whole plant $\mathrm{CO}_{2}$ exchange, carbon allocation, and osmoregulation in oak seedlings, Ann. Sci. For. 53 (1996) 447-459.

[34] Wright G.C., Smith R.C.G., Morgan J.M., Differences between two grain sorghum cultivars in adaptation to drought stress. III. Physiological responses, Aust. J. Agric. Res. 34 (1983) 637-665.

[35] Wright P.R., Morgan J.M., Jessop R.S., Turgor maintenance by osmoregulation in Brassica napus and B. juncea under field conditions, Ann. Bot. 80 (1997) 313-319.

[36] Zhang J., Nguyen H.T., Blum A., Genetic analysis of osmotic adjustment in crop plants, J. Exp. Bot. 50 (1999) 291-302.

To access this journal online: www.edpsciences.org 